\title{
LIBERDADE E NATUREZA HUMANA EM MAQUIAVEL
}

Antonio Ruzza*

RESUMO: Maquiavel se apresenta como o filósofo mais representativo das mudanças ocorridas na passagem entre a Idade Média e a Idade Moderna. Pela leitura das suas obras que tratam de política e moral, leitura livre dos conhecidos preconceitos que elas suscitaram na sua época, verificamos que ele, a partir do estudo da História (tanto greco-romana quanto medieval), desenvolve um conceito original de liberdade, que consegue conciliar o elemento coletivo / público e o individual / privado, sendo esse último um traço dominante na futura sociedade industrial. Ele apresenta uma concepção realista e pessimista da natureza humana, que se caracteriza pelos desejos, o espírito conflitivo e a ambição. Essas características não podem ser freadas nem eliminadas (como pensavam Platão, Aristóteles, Agostinho, etc.), mas devem ser oportunamente aproveitadas e endereçadas para o bem comum (república). Assim, Maquiavel inicia a dissolução de toda uma tradição filosófica e político-moral.

Palavras-chave: liberdade, ambição, Estado, Roma, Virtù.

ABSTRACT: Maquiavel presents himself as the most representative Philosopher of the changes that occurred in the passage between middle and modern ages. By reading his works dealing with politics and morality, free reading of the well-known prejudices frequently evokedin his time, we realized that, from the history studies (both Greco-Roman and medieval), he develops an original concept of freedom, which can reconcile the collective / public and the individual / private elements, where as the latter being is a dominant feature in the future industrial society. He presents a realistic and pessimistic conception of human nature, which is characterized by desires, conflicting and ambition spirit. These characteristics cannot be restrained or eliminated (as Plato, Aristotle, Augustine, etc... has thought) but they should be opportunely harnessed and addressed to the public welfare (republic). Thus, Machiavelli initiates the dissolution of an entire philosophical and political-moral tradition.

Keywords: freedom, ambition, state, Rome, virtù.

\section{Introdução}

\footnotetext{
* Graduado em Engenharia pelo Politécnico de Torino (Itália) e em Filosofia pela USJT. Pós-graduado em "Docência para o ensino superior" pelo UNIFAI. Mestre em Filosofia (Epistemologia da Política e do Direito) pela USJT. Doutorando em Filosofia pela PUC. Docente de Filosofia no UNIFAI, no qual organizou vários grupos de estudo. Publicou Rousseau e a moralidade republicana no Contrato Social (2010) e Em nome das luzes: um desafio à religião (2012), ambas pela Annablume. Publicou o artigo A solução para o problema do absurdo em Albert Camus no livro Deus entre a Filosofia e a Teologia Contemporânea, de 2014, editado pela Appris.
} 
Desde a publicação do Príncipe, em 1513, existe uma leitura tradicional, distorcida e tendenciosa, que apresenta Maquiavel como defensor do absolutismo (príncipe acima da lei e com poderes concentrados) e do imoralismo em política (pelo qual o fim justifica os meios, então, é possível recorrer ao uso da mentira, à má-fé, à astúcia, à traição, à violência, à hipocrisia; deve-se simular e dissimular, aparecer sem ser, etc.). Esta leitura foi compartilhada não só por moralistas e conservadores, mas também por revolucionários.

Entendemos que a leitura correta deve considerar, em primeiro lugar, a necessidade de reconstruir o contexto no qual as suas obras foram originariamente concebidas, o
contexto intelectual da filosofia clássica e do Renascimento junto àquilo da vida da
cidade-estado italiana no início do século XVI. Uma vez reconstruído isso [...],
poderemos iniciar a apreciar a extraordinária originalidade da sua polêmica contra as
concepções éticas que dominavam a sua época (SKINNER, Q. 1999, p. 10). ${ }^{1}$

Trata-se de um contexto histórico de mudanças culturais no início da Idade Moderna (por exemplo, a superação de uma visão exclusivamente religiosa da sociedade, a busca de metas individuais, o antropocentrismo da Renascença). A partir do chamado Humanismo Cívico italiano do século XV (que tem um precursor em Petrarca, no século anterior), estudado por Hans Baron, Maquiavel opera um extraordinário avanço. Depois, precisa considerar a obra do florentino na sua totalidade: um primeiro objetivo é manter o poder e reforçar o Estado, porque nada é pior do que a ausência do Estado (esse é o objetivo do Príncipe); depois, defender um governo republicano ${ }^{2}$ (esse é o objetivo dos Discorsi).

Isto significa que Maquiavel se afasta da política normativa de antigos e medievais, que definiam como devia ser o governante bom e justo, e quais as suas virtudes (situação que quase nunca aconteceu). Para ele, precisa governar sem valores dados a priori, mas conforme as circunstâncias, e o príncipe será avaliado pelos resultados e não pelas intenções (como sempre aconteceu). O florentino não inventou nada, mas transformou uma prática (apreendida nas leituras dos antigos e nas missões diplomáticas pela República de Florença) em uma teoria que pudesse ser conhecida por todos aqueles que querem entender a política realista. Assim comenta um poeta italiano do século XIX: "Io quando il monumento vidi ove posa il

\footnotetext{
${ }^{1}$ A tradução da língua italiana é nossa.

${ }^{2}$ Com este termo devemos entender o regime do bem comum, e não uma forma oposta à monarquia (como entendido hoje). Então, é possível uma monarquia republicana.
} 
corpo di quel grande, che temprando lo scettro ai regnatori gli allòr ne sfronda, Ed alle genti svela di che lagrime gronda e di che sangue ..." (FOSCOLO, U., 1951, p. 106). ${ }^{3}$

Maquiavel separou política e moral, que andavam juntas no mundo antigo e medieval (ou talvez introduziu uma nova forma de moral), porque as virtudes cristãs podem ser boas no âmbito privado, mas não no público, para governar e conviver com pessoas de diferentes desejos e objetivos. Assim, ele pode ser considerado o fundador da ciência política, ${ }^{4}$ a partir de uma nova concepção da natureza humana e pelo estudo atento da História.

\section{Generalidades sobre o pensamento político de Maquiavel}

Por isto, por uma leitura mais atenta e menos preconceituosa, Maquiavel foi já reavaliado antes do século $\mathrm{XVIII}^{5}$ e incluído na tradição republicana: ele recomenda os meios pouco "ortodoxos" só em casos extremos, e sempre no interesse do bem comum; em situações normais, o governante deve seguir as leis, como todo cidadão; então, o príncipe de 'virtù'6 não é um tirano, aquele que busca o bem particular e exerce o poder com arbitrariedade. $\mathrm{O}$ florentino apresenta ideias democráticas, quando afirma que o príncipe deve buscar o apoio do povo e não dos "grandes" (as famílias poderosas), e deve evitar o ódio, sem entretanto contar com o amor eterno dos súditos, por causa do caráter volúvel e ingrato das pessoas.

O florentino apresenta também outras ideias típicas do republicanismo moderno: o governo deve ser misto, ${ }^{7}$ isto é, com consenso e participação de todos os grupos; o governante deve estar sempre preparado para a guerra, porque a pátria livre está acima de tudo e porque

\footnotetext{
3 Tradução da língua italiana: "Quando eu vi o monumento onde está o corpo daquele grande homem, que ensinando aos governantes a serem mais fortes, os desnuda da aparência, e mostra aos povos quantas lágrimas e sangue eles provocam ...".

${ }^{4}$ Não devemos entender "ciência" em sentido moderno, como um conhecimento seguro ou definitivo, porque isto não se aplica ao campo da ação humana, que tem um aspecto imprevisível; mas como algo que pode ser estudado por meio de um método.

${ }^{5}$ Geralmente, se considera Spinoza o primeiro grande filósofo a rever as opiniões negativas. Na mesma linha operaram alguns iluministas, em particular, Rousseau, que define o Príncipe o livro dos republicanos, porque fingindo dar lições aos reis, as dá aos povos.

${ }^{6}$ Ao longo do artigo, explicaremos melhor o conceito de 'virtù'. Podemos adiantar que ela é a capacidade (por parte do governante) de reagir quando a 'fortuna' (o acaso, o imprevisto) lhe é hostil, para revertê-la em seu favor. No caso do povo, é o que permite a busca do bem comum e a manutenção da república.

${ }^{7}$ Aqui, existe uma clara influência de Aristóteles e do modelo da República Romana com cônsules, senado e tribunos da plebe (representantes respectivos dos elementos monárquico, aristocrata e popular). Em todo caso, trata-se de um esboço da futura teoria da divisão do poder.
} 
só pensar na paz enfraquece o cidadão; deve estar sempre pronto, audaz e ativo (nunca passivo) contra os golpes adversos da 'fortuna', mesmo que isso não lhe garanta o sucesso, porque o mundo da política é o mais instável; deve contar com as próprias forças e não com aliados poderosos. Sendo capaz de tudo isso, podemos concluir que ele possui 'virtù'.

O principal objetivo de Maquiavel é a defesa da liberdade e do sistema republicano. Ele resgata o conceito de liberdade baseada em direitos, ${ }^{8}$ conforme os antigos gregos (Aristóteles) e romanos (Cícero) ${ }^{9}$ : desejo de não se submeter nem de ser dominado; participação política; respeito das leis; patriotismo; união de interesses; busca do bem comum. Esta concepção garante a igualdade de direitos (não a igualdade econômica, problema que se apresenta só séculos depois) e combate as vantagens indevidas. ${ }^{10}$ Mas acrescenta: a liberdade consiste também em poder buscar algo individual para destacar-se da igualdade total, conforme tendência antropocêntrica do Humanismo Cívico e pelo reconhecimento de um sentimento natural que não pode ser eliminado: a ambição, como trataremos adiante. Por causa disto, o homem busca riqueza ou glória. O Estado deve incentivar a segunda, que se reverte em benefício de todos (a glória da nação) e não só do indivíduo (a riqueza). Este é o caso do regime republicano.

Assim, para Maquiavel, a liberdade consiste em duas coisas: ter direitos dentro da igualdade jurídica que permite a participação aos assuntos públicos; poder destacar-se buscando a glória. Quando a liberdade é perdida pela corrupção ou pela conquista feita por outra nação, a ideia é mantida, e o povo tentará recuperá-la. Em compensação, ela não é apreciada por um povo que nunca a teve (como os bárbaros asiáticos, que sempre foram submissos um governo tirânico). ${ }^{11}$ Os seus inimigos devem ser eliminados sem hesitar. ${ }^{12}$

\footnotetext{
${ }^{8}$ Estes direitos não eram possuídos pelos não-cidadãos na polis grega (escravos, mulheres, estrangeiros, etc.) e pelos povos bárbaros.

${ }^{9}$ Entretanto, no tema das virtudes, os dois discordam completamente. Por exemplo, Cicero condena por princípio Rômulo, que matou o irmão que estava dificultando a organização da recém-fundada Roma. Maquiavel o elogia a posteriori, pelos bons resultados alcançados no bem comum.

${ }^{10}$ Maquiavel cita o exemplo do rico romano Mumio, que em época de carestia, fez uma distribuição gratuita de alimentos ao povo, se beneficiando nas eleições. Este ato (louvável do ponto de vista cristão) provocou a sua condenação à morte, porque foi considerado ato de corrupção. Ele deveria ter feito a doação anônima ao Estado, que teria repassado ao povo.

11 Exemplos mais conhecidos: egípcios (faraó) e persas ("grande rei”). Estes povos eram considerados "não livres" pelos greco-romanos.

${ }^{12}$ Aqui vale exemplo de Bruto com a exaltação do tiranocídio (contra Júlio César).
} 
A corrupção, que é normal nos governos degenerados, é a grande inimiga da república e penetra com o tempo, por causa de certas tendências da natureza humana: se parcial, a liberdade pode ser recuperada, mudando o regime (caso da monarquia em Roma); quando total, a solução pode ser um líder revolucionário extraordinário, ou a mudança das instituições, mas isto é difícil e pode levar à tirania. Para evitar a corrupção precisa: manter a união dos cidadãos em torno do objetivo comum; manter a situação de necessidade, pela qual é vantajoso unir as forças; renovar os antigos valores; produzir líderes virtuosos, mas evitar os ambiciosos; valorizar o interesse público sobre o privado; garantir a aplicação das leis; fiscalizar os governantes e participar do debate público; evitar a ousadia do povo quando este quer mais poder só para humilhar a aristocracia ou apossar-se dos bens dela.

Resumindo, Maquiavel desenvolve uma concepção político-social moderna: separa Estado (assuntos terrenos) e religião (assuntos espirituais); defende o governo republicano misto; coloca a política como ação e com moral própria; derruba certas ideias tradicionais como aquela da paz, ${ }^{13}$ defendendo que os povos progridem pelos tumultos; valoriza o povo, porque este busca sair das formas degeneradas que lhe tiraram a liberdade, e porque o príncipe deve temê-lo e porque é ele o guardião da liberdade republicana.

Afinal, Maquiavel não é maquiavélico!

\section{O pensamento de Maquiavel sobre a natureza humana}

O autor dos Discorsi demonstra-se um grande conhecedor da alma e do comportamento humano, tendo uma visão sobre o homem que podemos definir ao mesmo tempo realista e pessimista. Sobre a natureza humana:

Sua hipótese: a política é o que é porque o homem é o que é [...], devemos perceber que agimos de uma maneira e fingimos agir de outra. Que somos uma coisa e imaginamos ser outra. Não por hipocrisia, mas por fraqueza. Somos fracos demais para admitir, para nós mesmos e para os outros, que agimos movidos por desejos egoístas [...]. Não admitimos ser o que somos e acreditamos ser aquilo que apenas desejamos ser (POMPEU, J., 2011, p. 8).

\footnotetext{
${ }^{13}$ Paz que tampouco era realizada na prática. Para Agostinho, o objetivo da boa política era a paz, que permitia a vida de meditação e contemplação.
} 
Ele entende que a natureza humana é portadora de desejos, que são os moventes das ações; mas muitos deles não podem ser satisfeitos, ou porque impossíveis (ambiciosos demais), ou por obstáculos externos, ou por falta de disposição do indivíduo em lutar por eles. Isso deixa os homens, que já podemos definir entrados na modernidade, permanentemente descontentes. Também o que é conseguido já não é mais objeto de desejo: o homem continua insatisfeito $^{14}$ e busca algo mais, fato que garante o dinamismo da vida humana, a menos que não seja completamente sufocado por uma autoridade externa, como a religião dominante no mundo medieval. ${ }^{15}$ Os indivíduos são mais ou menos sempre os mesmos, por causas dos desejos e dos humores, mas as situações mudam continuamente, por causa da 'fortuna' (o acaso, o imprevisto) e de novas situações, no caso, as mudanças sociais e culturais provocadas pela passagem da Idade Medieval para a Moderna (maior circulação do dinheiro, primeiras manifestações da burguesia, fortalecimento das monarquias nacionais, grandes navegações com descobertas de outras culturas, decadência do sistema feudal). Nada é previamente determinado nos acontecimentos políticos; a história (diferentemente da natureza física) não tem leis fixas, só pode fornecer indícios de comportamento em situações parecidas.

É importante observar que afirmar a existência de uma natureza humana (a partir de muitas semelhanças de comportamento entre os homens ao longo da história) não significa defender uma forma de determinismo:

Somos plenamente capazes de tudo que qualquer homem faz, mas uma série de circunstâncias nos leva a desenvolver ou não, determinada potencialidade. Assim, fala-se de uma natureza humana em potência e de indivíduos em ato. Isto permite, simultaneamente, definir uma espécie e apontar singularidades (POMPEU, J., 2011, p. 40).

Os homens devem lidar com as circunstâncias, que não dependem deles, mas da 'fortuna' e de mudanças históricas e sociais não planejadas. Portanto, podemos dizer que eles têm tendência ao mal, se entendemos ser um mal tentar realizar os seus desejos prejudicando necessariamente os outros; evitam o mal por falta de oportunidade ou porque não vale o risco; fazem o bem só por necessidade. Por causa dessa tendência natural, com o tempo, até a

\footnotetext{
${ }^{14}$ É conhecida a frase de Oscar Wilde: "Há duas tragédias na vida humana: uma, a de não satisfazermos os nossos desejos; a outra, a de os satisfazermos." (POMPEU, J., 2011, p. 59).

${ }^{15}$ Agostinho afirma que a felicidade consiste em não desejar nada, porque se evita tanto a frustração de não conseguir o bem desejado, quanto o medo de perdê-lo caso seja obtido. Foi um pensamento influente, que perdeu força a partir do antropocentrismo moderno.
} 
melhor entre as sociedades tende à corrupção, quando prevalece o interesse particular e a 'virtù' declina.

Esta natureza humana pode ser corrigida ou regulada, mas não modificada, pela educação ao bem público e pelas boas leis, que impõem limites às ações dos desejantes; pode ser esquecida ou refreada por uma necessidade superior e irresistível; mas pode aflorar a qualquer momento. Por causa dessa natureza, nenhum sistema político poderá ser completamente satisfatório, no sentido de dar respostas completas a todos os desejos humanos, sempre diferentes; não poderá ser tão perfeito ou utópico, tal que mude a natureza humana e elimine o surgimento de novos desejos; só será preferível a outro (seria o caso da república), porque oferece mais condições de realização. As discórdias são inevitáveis entre os "grandes" que querem oprimir e o povo, o qual não quer ser oprimido; bem como entre indivíduos particulares. Para evitar a destruição da sociedade, as discórdias devem ser geridas dentro da lei para permitir o progresso e a grandeza da república. As boas leis são frutos dos conflitos infinitos de desejos opostos, sem solução definitiva, mas mutável conforme as contingências.

A este respeito, Maquiavel rompe uma tradição cristã estabelecida há séculos, e ainda seguida pelos humanistas cívicos do século anterior, pela qual a paz e a concórdia eram o valor supremo da vida associativa ${ }^{16}$ :

ele mostra que é melhor esquecer este projeto, que aliás nunca evitou os conflitos e muito menos a guerra [...] ou seja, se os conflitos são inevitáveis e fazem parte da natureza dos homens, o importante não é suprimi-los, mas sim evitar que destruam a possibilidade de convivência entre os membros de uma mesma comunidade política. $\mathrm{O}$ que cabe, portanto, é buscar criar um conjunto de instituições que ofereçam uma arena na qual os embates ocorrerão (BIGNOTTO, N., 2003, p. 50). ${ }^{17}$

O florentino rompe também com a visão (típica de Platão ou Agostinho) de um homem dual, dividido entre razão e paixões, sendo que a vitória da primeira causa o bem, e a da segunda, o mal. Para ele,

o homem é razão e paixão, simultaneamente. Ambos são atributos do agir de um mesmo ser, e não disposições contrárias. Uma não prevalece sobre a outra.

\footnotetext{
${ }^{16}$ Também Platão e Aristóteles perseguiam o ideal da harmonia dentro da 'polis'.

${ }^{17}$ É assim explicada uma das causas da grandeza da República Romana: pelos conflitos, todos os grupos sociais progrediam, e conseguiam manter a união. Onde há paz, há submissão e imobilismo social.
} 
Conspiram para uma causa comum: satisfazer desejos. $\mathrm{O}$ homem maquiavélico não está em guerra consigo mesmo, mas com o que o impede de alcançar o que deseja, contra o que lhe entristece, sejam coisas na natureza, sejam outros homens (POMPEU, J., 2011, p. 9).

Uma concepção desse tipo é também oposta ao ideal proposto por Aristóteles, do homem virtuoso que descobre e age pelo "justo meio":

\begin{abstract}
a grandeza do homem não consiste em equilibrar entre si as paixões opostas, até anulá-las, por meio da razão, mas em levar até o extremo a lógica das paixões. Esta lógica nos faz compreender porque o dinamismo da ambição humana não encontra repouso [...]. O motor da luta e dos conflitos está no coração do homem, não nas contradições da sociedade, porque ele permanece idêntico a si mesmo ao longo da história (BRAUN, R., 2003, p. 84). ${ }^{18}$
\end{abstract}

A ruptura do modelo dual não é definitiva, parece um pensamento ainda isolado na Idade Moderna, pois a influência do dualismo cartesiano será bem maior, talvez por ser mais explícito. Filósofos posteriores e de visão oposta entre si, como Hobbes e Rousseau, concebem também um homem dividido entre razão e paixões, com uma natureza a ser superada e outra pronta a fundamentar uma outra ordem social, por um contrato que põe término a um estado de natureza. Assim, eles pensam no homem como deveria ser, não como é. Neles, a natureza humana torna-se a descrição de uma realidade imaginada ou metafísica, não histórica. Maquiavel é um realista: se a natureza humana não pode ser muito diferente do que é, é inútil emitir julgamentos morais absolutos, dividir os homens entre "bons" e "maus", sendo que os "maus" são sempre os outros, pelos nossos critérios valorativos, porém, arbitrários.

Então, o homem, sobretudo quando está no poder, faz o bem só por necessidade ou cálculo: vive de aparências, engana e se faz enganar facilmente, tende pela ambição à corrupção, que é a busca da vantagem individual. O governante cria a sua própria moral, diferente daquela do homem comum. Assim, o autor do Príncipe não teria eliminado a moral, mas criado duas: a pública e a privada.

Entretanto, este mesmo homem, mau na primeira oportunidade, é capaz de ser o guardião da liberdade; de ter um papel participativo e eficiente no governo misto da república, que

\footnotetext{
${ }^{18}$ A tradução da língua espanhola é nossa.
} 
assim pode durar séculos (como o caso de Roma e Esparta); de organizar tumultos, para obter e manter direitos (já que, como dito, é utópico pensar que não existe conflito de interesses mesmo na melhor sociedade); de elaborar as boas leis; de compreender que ele viverá melhor se realiza e defende o bem comum. O homem apresenta sede de novidades, por causa da insatisfação que o faz reclamar do presente, sentir saudade do passado e esperar num futuro melhor. Consequentemente,

a "natureza humana" não pode ser reduzida a uma essência que, ao se manifestar, reduziria as ações humanas a uma luta sem esperança contra a corrupção. Só podemos situá-la na origem das sociedades se levarmos em conta que a mudança é própria da política e não pode ser compreendida como movimento em direção a apenas um fim (BIGNOTTO, N., 1991, p. 173).

A função da sociedade, sem falsos escrúpulos e ilusões, não consiste em tentar mudar a natureza humana, mas, por meio das boas leis e da percepção do bem comum, evitar que ela se manifeste nos seus aspectos negativos.

Não sendo a natureza humana uma essência, Maquiavel se desinteressa pela definição dos gregos de uma sociabilidade natural. Assim, uma reunião de homens individualmente com tendência ao mal pode criar uma sociedade sadia: nada está definido de antemão. E isso não indica nenhuma contradição ou paradoxo! A sociedade sadia, a república, dura mais que as outras, porque conta com um sistema de boas leis que regulam as relações sociais; porém, nem ela é eterna, por causa da natureza humana que criará novos obstáculos e de mudanças externas, imprevistas ou não planejadas. ${ }^{19}$

Em suma, existe uma natureza humana e a sua marca é um sentimento que não pode ser eliminado: a ambição. A razão não serve para controlar os desejos, mas para descobrir os meios de realizá-los. Não devemos criticar a ambição, mas julgar os seus resultados por parte daqueles que são afetados:

Acreditar que um desejo seja realizável, ambicionar algo, não é o mesmo que obtêlo. É preciso lutar, arrancar do destino e das ambições alheias aquilo que ambicionamos. Mas isso requer talento. Alguns se lançam em tal empreitada e promovem a desgraça própria e alheia. Outros encontram a glória e trazem benefícios para muitos. Não se pode condenar o ambicioso, afinal todos o somos e não podemos deixar de sê-lo. Mas podemos condenar aqueles que pecam por seus

\footnotetext{
${ }^{19} \mathrm{O}$ bom exemplo poderia ser a Revolução Industrial.
} 
desejos, que não medem as consequências de suas ambições e, ao persegui-las cegamente, provocam apenas a destruição (POMPEU, J., 2011, p. 82).

O moralismo tradicional condena a ambição, opondo-lhe a virtude da humildade. Maquiavel entende que ela é movente da ação humana e na república pode dar bons resultados, como a liberdade, a grandeza e o bem comum: somente estes são os fins que justificam os meios (e não qualquer fim, conforme a maior acusação dirigida ao florentino como marca de imoralidade). A desgraça do homem não é ter desejos e ambição, mas é a falta de 'virtù' para realizá-la quando é razoável, ou para controlá-la quando é desmedida. Claramente, isso é mais prejudicial no governante do que no homem comum. Assim, a 'virtù' pode ser entendida como uma razão prática para conquistar o que ambicionamos pelos desejos: ela está relacionada mais à eficácia do que à noção de bem. Certas qualidades consideradas virtudes levam à ruina; outras consideradas vícios trazem bons resultados. Isso explica porque, na política, não tem espaço para as virtudes platônicas, aristotélicas ou cristãs.

\section{A concepção da liberdade nos Discorsi}

Esta é a obra na qual está mais clara a preferência de Maquiavel para o regime republicano. Estudando os eventos civis e militares da República Romana, que durou cinco séculos, ${ }^{20}$ ele quer pesquisar as causas da sua grandeza e duração. Devido à extensão do tema, nos limitaremos a comentar alguns capítulos do livro II, no qual encontramos pontos para aprofundarmos na sua concepção de natureza humana e de liberdade.

Os humanistas cívicos do século XV já mostravam interesse para um novo conceito de liberdade,

intimamente ligado àquele de independência [...], nenhuma cidade podia se dizer livre se não pudesse governar seus interesses sem a interferência de outros povos e instituições. Buscar o desligamento do domínio de muitos séculos da Igreja era uma tarefa essencial para a construção de uma república. Para que a liberdade se transformasse em algo mais do que um sonho, era necessário que os cidadãos

${ }^{20}$ É entretanto necessário observar que o Império que substituiu a República manteve várias instituições e formas dessa última. Também ele durou mais cinco séculos. 
adotassem um modelo de vida que os levasse a se interessar pelos negócios da sua cidade (BIGNOTTO, N., 2003, p. 42). ${ }^{21}$

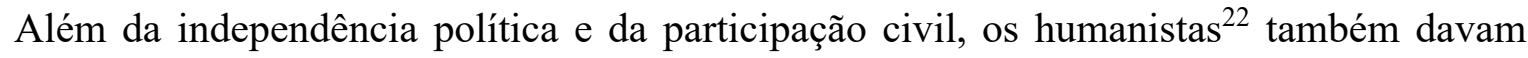
ênfase à luta contra a tirania interna, representadas pelas grandes famílias (os 'signori'), como os Medici em Florença:

Para que isso fosse possível, era necessário um sistema de leis que, além de impedir
os mais ricos de ocupar o poder, garantisse uma efetiva igualdade entre os cidadãos.
Para Bruni, a constituição florentina garantia a igualdade a partir do momento em
que fazia da 'virtù', e não da riqueza, o requisito necessário para a postulação de um
cargo público [...] a liberdade significava, antes de mais nada, igualdade diante da lei
(BIGNOTTO, N., 1991, p. 46).

A 'virtù' não era um valor ético, mas um fator objetivo para a vida ativa. Mas, segundo Bignotto, os humanistas cívicos geralmente confiavam a conquista e defesa da liberdade à parte aristocrática e culta da cidade, ou à incipiente burguesia. ${ }^{23}$ Ao contrário, Maquiavel afirma que a parte popular está mais motivada em defender um governo republicano, que oferece maiores garantias aos seus direitos civis e ao desejo de não ser dominado e oprimido pelos chamados "grandes", porque o povo não busca propriamente o poder.

Entretanto, o comentador Bignotto observa que a confiança no povo não é absoluta (como será, por exemplo, para os primeiros marxistas), porque também o povo pode se corromper ou mostrar-se exageradamente ambicioso na busca de uma igualdade absoluta, ou aceitar tiranos e demagogos que se proclamam amigos do povo. Este pensamento é compatível com a concepção pessimista da natureza humana e da existência de conflitos internos que nunca serão eliminados; somente controlados e bem geridos. Esta valorização relativa do povo é confirmada por outras considerações:

não é possível fundar uma república ou um principado pela 'virtù' das massas, porque as diferentes opiniões lhe impedirão de ser aptos a organizar um Estado. Segue que para ordenar uma república é necessário um homem só. Além disso, quando uma cidade declina pela corrupção, se acontecer que se recupere, sempre

\footnotetext{
${ }^{21}$ As repúblicas medievais italianas eram continuamente ameaçadas pelo Papado e pelo Sacro Império RomanoGermânico, sendo arrastadas na luta entre estas duas grandes instituições.

${ }^{22}$ Os mais conhecidos são Salutati, Bracciolini e Bruni, que exerceram cargos públicos em Florença.

${ }^{23}$ Este era o modelo da 'Serenissima Repubblica di Venezia'.
} 
acontecerá pela 'virtù' de um homem vivo naquele momento e não pela 'virtù da totalidade dos cidadãos (SKINNER, Q., 1999, p. 64). ${ }^{24}$

Em todo caso, o modelo pelo qual o povo é o melhor guardião da liberdade assim concebida é a Roma republicana. Esta observação será compartilhada por Montesquieu:

Se o povo foi cioso de seu poder legislativo, o foi menos de seu poder executivo: deixou-o quase exclusivamente nas mãos do senado e dos cônsules, e quase só se reservou o direito de eleger os magistrados e de confirmar os atos do senado e dos generais [...]. O povo disputava ao senado todos os ramos do poder legislativo porque era cioso de sua liberdade; não lhe disputava os ramos do poder executivo porque era cioso da sua glória (MONTESQUIEU, C.-L., 1973, p. 169). ${ }^{25}$

O amor pela liberdade entendida em primeiro lugar como independência não era exclusivamente dos romanos:

Nada tornou mais difícil para os romanos a conquista dos povos vizinhos e de alguns mais distantes do que o amor que estes tinham pela liberdade, a qual defendiam com tal determinação que nunca teriam sido possível subjugá-los sem uma prodigiosa coragem [...] a história nos demonstra também que a perda da independência expõe os povos e as cidades a verdadeiros desastres (MAQUIAVEL, N., 1979, p. 197). ${ }^{26}$

Afinal, os romanos acabaram vencendo os outros povos, não pela 'fortuna' (como sustentaram Plutarco e também Tito Lívio), mas pela 'virtù', que deve pertencer não só aos líderes, mas à comunidade inteira: maior disciplina e organização militar; patriotismo, que aumentou depois que foi liquidada a monarquia (que, na definição de Tito Lívio e de Salústio, outro importante historiador romano, não é uma forma de Estado livre, no sentido que os súditos não são livres porque não se autogovernam): o interesse comum só é respeitado nas repúblicas e as poucas pessoas prejudicadas não atrapalham. Pelo contrário, se um tirano é hábil nas conquistas, só ele se beneficia.

\footnotetext{
${ }^{24}$ A tradução da língua italiana é nossa. A pessoa fundadora é chamada de legislador.

${ }^{25} \mathrm{O}$ senado era considerado habilidoso em conduzir as guerras, fazer tratados de paz ou amizade, sempre com firmeza e decisão em defender os interesses de Roma, permitindo a sua glória. O povo contava com os tribunos da plebe, que podiam vetar qualquer lei decidida pelo senado. O terceiro polo na divisão do poder eram os dois cônsules (um de origem aristocrática, outro popular), que deviam tomar as decisões juntos. A relação entre os grupos era conflitiva, situação que para Maquiavel era condição de progresso e igualdade.

${ }^{26}$ Nesta edição, o tradutor utilizou o termo "comentários" para os Discorsi, mas nós preferimos o termo "discursos".
} 
Vencedores ou vencidos, os povos da antiguidade ${ }^{27}$ amavam a liberdade, não por idealismo, mas por motivos práticos: ser poderosos e enriquecer. "Falar de liberdade não é, pois, falar de uma forma política estável, mas da criação contínua das condições da potência" (BIGNOTTO, N., 1991, p. 93). O florentino lamenta que o amor para a liberdade era bem maior entre os antigos do que entre os seus contemporâneos; podia se manifestar em um grau suficientemente elevado, como entre os florentinos, que apreciavam os apegos às leis e o debate institucional; mas eles não

\begin{abstract}
sabiam reproduzir as virtudes dos primeiros tempos. Assim, por exemplo, contra o costume florentino de deixar para depois as decisões mais importantes, ele mostra que os romanos atacavam de frente as principais dificuldades, para evitar que os seus inimigos e a deusa fortuna se servissem das suas hesitações para ganhar terreno (BIGNOTTO, N., 2003, p. 47).
\end{abstract}

A prudência excessiva não é uma virtude. As rápidas vitórias faziam com que Roma fosse temida e os vizinhos hesitassem em atacá-la, deixando esta iniciativa a ela, ou se satisfazendo com um tratado de amizade, que seria violado pela Urbe quando os interesses das duas partes não coincidissem mais. A lição é que não se fazem pactos com o mais forte; todos aqueles povos se enganaram porque não possuíam a 'virtù' em grau tão elevado como os romanos.

Maquiavel individua duas causas da decadência da sua época: a educação cívica que não existe mais, e a religião cristã. Sobre esta, Maquiavel fornece a sua dura interpretação, superando a prudência dos humanistas cívicos:

nossa religião, mostrando a verdade e o caminho para a salvação, diminui o valor das honras desse mundo [...] só santifica os humildes, os homens inclinados à contemplação e não à vida ativa. Para ela, o bem supremo é a humildade, o desprezo pelas coisas do mundo. Já os pagãos davam a máxima importância à grandeza da alma, ao vigor do corpo, a tudo, enfim, que contribuísse para tornar os homens robustos e corajosos (MAQUIAVEL, N., 1979, p. 199).

\footnotetext{
${ }^{27}$ São os vários povos itálicos, os cartaginenses, os gauleses, os gregos, os germânicos. Não são considerados os povos orientais, submissos a um rei considerado de origem divina.
} 
Para ele, a religião deve ser um instrumento, com função civil e educativa ${ }^{28}$ : não precisa de uma fé que enfraquece, mas de rituais sem interioridades, que unem e fortalecem. Mas o Cristianismo valoriza a humildade e a contemplação; não a glória e a vida ativa, que são a marca do homem com 'virtù'. ${ }^{29}$ A virtude cristã é uma atitude passiva diante do mundo que expressa a vontade divina, portanto, imutável. O livre-arbítrio nada tem a ver com a liberdade, é apenas a escolha entre obedecer a Deus ou pecar; foi inventado para isentar Deus da responsabilidade da existência do mal. Para um bom cristão, não faz diferença ser governado por um tirano ou uma república; não existe sentimento de pátria; o povo não é mais uma força política, mas um rebanho conformado e sem direitos, que só aguarda a salvação no outro mundo. O Império Romano ${ }^{30}$ preparou o caminho para a perda da liberdade; quando caiu, foi substituído pelo Império Cristão, que acelerou o processo. ${ }^{31}$ Maquiavel rompe esta tradição de doze séculos. A Igreja é também responsável por ter tornado fracos e descrentes os italianos dos vários Estados, e de mantê-los divididos.

Dos ativistas cristãos, o florentino critica um outro aspecto:

sente-se a intensidade com que perseguiram o que podia lembrar a antiguidade: queimando os escritos de poetas e historiadores, derrubando estátuas, mutilando o que trazia a marca dos tempos antigos. Se uma nova língua tivesse favorecido esse trabalho, em poucos anos tudo estaria esquecido (MAQUIAVEL, N., 1979, p. 209).

Apesar destas afirmações, que claramente provocaram a hostilidade das autoridades eclesiásticas, Cassirer observa que no sistema de Maquiavel,

a religião é indispensável. Mas não é mais um fim em si próprio; transforma-se numa simples ferramenta na mão dos dirigentes políticos. Não é a base da vida

\footnotetext{
${ }^{28}$ A religião foi usada assim, de forma vantajosa, por Numa entre os romanos e Moisés entre os judeus, para criar um povo a partir de uma multidão.

${ }^{29}$ Agostinho (na Cidade de Deus) substitui as virtudes cívicas romanas (liberdade, glória e domínio) com as virtudes cristãs (submissão, humildade, paz). O famoso historiador E. Gibbon, em Declínio e queda do Império Romano, identifica a causa principal da queda do mundo romano na ação antipatriótica do Cristianismo que (em nome da fraternidade) recusava o serviço militar, no momento das grandes invasões barbáricas. Esse fato obrigou o exército romano a se servir de mercenários bárbaros para lutar contra outros bárbaros (sendo a invasão destes e a corrupção interna outros fatores que contribuíram para a decadência).

${ }^{30}$ O Império de Augusto substituiu a República após a fracassada tentativa de Júlio César de apoderar-se de todo o poder. É discutível qual fosse o real objetivo de César: tornar-se imperador ou salvar com a sua autoridade uma cidade dividida entre as facções. É interessante observar a tese de Pocock, um republicano contemporâneo, de que em todo caso a República Romana era condenada à autodestruição: por ser tão forte, cresceu demais, e só podia ser governada não mais pelo povo reunido em assembleia ou fiscalizando os governantes, mas por um imperador que concentrasse a maioria dos poderes (apesar de que foi mantida a instituição do Senado). Mas assim, o povo perdeu a sua liberdade.

${ }^{31}$ Também Rousseau, no Contrato Social, afirmou ser impossível uma república cristã.
} 
social do homem, mas uma poderosa arma para as suas ações políticas. Essa arma deve demonstrar a sua força pela ação. Uma religião meramente passiva, que evita o contato com o mundo em vez de organizá-lo, revelou-se a ruína de muitos reinos e Estados [...], o processo de secularização atingiu a fase final, porque o Estado secular existe não somente 'de fato', mas também 'de jure'; encontrou a sua definitiva legitimação teórica (CASSIRER, E., 2003, p. 170). ${ }^{32}$

Na sua crítica aos seus contemporâneos, o florentino observa que a escravidão atual é de todos; na antiguidade, era só dos escravos. A liberdade permitia saber também que um indivíduo era capaz "de chegar, pelas suas qualidades, às posições mais elevadas" (MAQUIAVEL, N., 1979, p. 200), desejo que faz parte da natureza humana. Isso era possível porque viviam em um clima de legalidade, coisa impensável numa monarquia que privilegia os amigos submissos ou numa tirania que a qualquer momento retira os direitos. Assim, a liberdade permite os progressos e a grandeza dos povos. ${ }^{33}$ É uma dupla concepção da liberdade: não submissão a nada, exceto à lei; possibilidade de ascensão individual. Dito em outras palavras:

Aquilo que em primeiro lugar pensa Maquiavel em atribuir à liberdade uma tão grande importância é que uma cidade que visa à grandeza deve ficar livre de qualquer forma de servidão política, seja interna imposta por um tirano, seja externa por uma nação imperial. Isso significa dizer que uma cidade é livre quando se mantém independente de qualquer autoridade que não seja da própria comunidade. A liberdade vem assim a identificar-se com o autogoverno (SKINNER, Q., 1999, p. $61){ }^{34}$

Segue a teoria de que um indivíduo pode ser livre somente num Estado livre, teoria que Skinner afirma ter sido defendida pelos chamados neo-romanos que participaram da Revolução Inglesa nas suas várias fases no século XVII: Harrington, Milton, Sidney, Osborne, Needham e outros, que sofreram a influência do florentino. Skinner, na obra Liberdade antes do Liberalismo, após analisar as definições de Berlin de liberdade positiva e negativa, ${ }^{35}$ propõe uma terceira definição fora as duas clássicas, mostrando uma faceta

\footnotetext{
32 Ele considera Maquiavel o fundador da concepção moderna de Estado, que ganhou autonomia completa, separado do poder religioso.

${ }^{33}$ Esta concepção era compartilhada por alguns entre os humanistas cívicos. Hans Baron observa que "existe um vínculo intimo entre a liberdade e a força criadora. Quando Bruni glorificou a liberdade considerando-a ser a raiz da grandeza cultural e política de Florença, afirmou também que a fonte da vitalidade e o êxito da cidade era a oportunidade que oferecia a seus cidadãos de chegar a ocupar altas posições na vida pública e empregar o seu talento ao máximo". (BARON, H., 1993, p. 35. A tradução da língua espanhola é nossa).

${ }^{34} \mathrm{~A}$ tradução da língua italiana é nossa.

${ }^{35}$ A liberdade positiva consiste em ser "livre pela lei" porque a lei garante um conjunto de direitos; foi assim entendida por Rousseau e outros de tendência republicana. A liberdade negativa consiste em ser "livre da lei", no
} 
importante da liberdade, que pode ser destruída (às vezes com a concordância das pessoas) em um regime irresponsável e tirânico, isto é, que controla todas as atividades do cidadão e tem como principal consequência colocá-lo numa situação de servidão material e moral. A solução parece ser um tipo modificado de liberdade positiva, que inclua todos os aspectos acima relacionados, mas que seja despojada daquela finalidade, ou melhor, pretensão, de resolver todos os problemas da humanidade (como pretendido por muitas revoluções), apesar de este objetivo ser o seu grande atrativo. A sua fundamentação não deve estar em um conceito da natureza humana de tipo metafísico e com fim moral. Neste caso, o inspirador deste modelo pode ser encontrado em Maquiavel, que defende um cidadão participante e não submisso a um poder opressivo, mas ao mesmo tempo desejoso de não ser impedido nas suas realizações pessoais para poder atuar sem depender do concurso de outro agente; é um cidadão concreto, o qual está no presente e não em um mundo ideal de difícil realização.

\section{Conclusão}

O livro II dos Discorsi permite entender melhor a concepção da liberdade defendida por Maquiavel. Esta concepção parece atrativa, porque (na interpretação de Skinner) une os aspectos mais vantajosos de cada um dos dois tipos tradicionalmente considerados opostos: o positivo mais atento ao coletivo, e o negativo, que privilegia o indivíduo. Ela se realiza só nas repúblicas. Entretanto, Maquiavel reconhece que "o objetivo das repúblicas é o seu próprio fortalecimento, com prejuízo de tudo o mais" (MAQUIAVEL, N., 1979, p. 200). O amor à liberdade, em uma república, leva necessariamente a dominar as outras, e não pode satisfazerse nunca, porque assim perderia a 'virtù' e caminharia rumo a ruína: “A multiplicidade dos Estados autônomos, em competição entre si, cria a vitalidade histórica” (BARON. H., 1993, p. 90).

Claramente, na atual visão do mundo que defende a igualdade de direitos de pessoas, povos e etnias, uma política de tipo expansionista não pode ser aceita, porque a liberdade do

sentido que o indivíduo é livre quando é isento de obedecer a uma lei coercitiva, é livre de fazer algo que a lei não impede. A definição encontra a sua origem em Hobbes. É a concepção típica do Liberalismo e do individualismo moderno, preferida por Berlin, que detecta na primeira concepção o risco do totalitarismo. 
poderoso provoca o fim e a submissão daquelas que se tornam ex-repúblicas. Entretanto, pelo contexto da época,

\begin{abstract}
A política romana é a expressão necessária de toda expansão comandada pelo desejo de liberdade. Se Roma exerceu a conquista melhor do que todas as outras cidades, ela o fez realizando uma essência que é comum a todas as repúblicas. Sua história é única, mas a sua singularidade está no fato de ter realizado uma tendência universal das formas livres de governo (BIGNOTTO, N., 1991, p. 111).
\end{abstract}

Poderíamos justificar as conquistas romanas dizendo que elas trouxeram um certo grau de civilização a povos mais atrasados, fato inegável; aliás, os próprios romanos absorveram a cultura grega que era mais adiantada. Mas esta política, justificada muitos séculos atrás, não o é hoje, porque poderia absolver o colonialismo dos três últimos séculos. As potências coloniais (franceses, ingleses, espanhóis, etc.) também argumentavam que estavam melhorando a vida de povos "não civilizados" trazendo infraestrutura (rodovias, ferrovias, hospitais, escolas) e educação; entretanto, mantiveram um sistema de exclusão ou discriminação dos nativos ${ }^{36}$ impuseram a própria religião, destruíram culturas e valores e provocaram uma série de problemas que ainda hoje afligem os países do chamado "Terceiro Mundo", assolados por guerras e fomes.

Em todo caso, temos de entender o contexto, o início da Idade Moderna, na qual se desenvolvem novas visões do mundo e da sociedade, e novas concepções da natureza humana, que pouco muda em um mundo em constante mudança. Nesse contexto, se insere a importância de Maquiavel em quebrar toda uma tradição, fato que consideramos inevitável e proveitoso, caso defendamos a ideia da necessidade do progresso humano.

\footnotetext{
${ }^{36}$ Por exemplo, eles não tinham (com poucas exceções) direito à cidadania do país conquistador, diferentemente do que acontecia com Roma.
} 


\section{BIBLIOGRAFIA}

BARON, H. Em busca del Humanismo Cívico Florentino. México: Fondo de Cultura Económica, 1993.

BIGNOTTO, N. Maquiavel. Rio de Janeiro: Zahar, 2003.

BIGNOTTO, N. Maquiavel republicano. São Paulo: Loyola, 1991.

BRAUN, R. Reflexión política y pasión humana enel realismo de Maquiavelo. In: VARNAGY, T. e BORON, A. (org.), Fortuna y Virtud en la República Democrática. Ensayos sobre Maquiavelo. Buenos Aires: Clacso, 2003.

CASSIRER, E. O mito do Estado. São Paulo: Codex, 2003.

FOSCOLO, U. Dei Sepolcri. In: Antologia della Letteratura Italiana. Torino: Paravia, 1961.

MAQUIAVEL, N. Comentários sobre a primeira década de Tito Lívio. Brasília: UnB, 1979.

MONTESQUIEU, C.-L. O Espírito das leis. São Paulo: Abril Cultural, 1973.

POMPEU, J. Somos maquiavélicos. Rio de Janeiro: Objetiva, 2011.

SKINNER, Q. Liberdade antes do Liberalismo. São Paulo: Unesp, 1998.

SKINNER, Q. Machiavelli. Bologna: Il Mulino, 1999. 